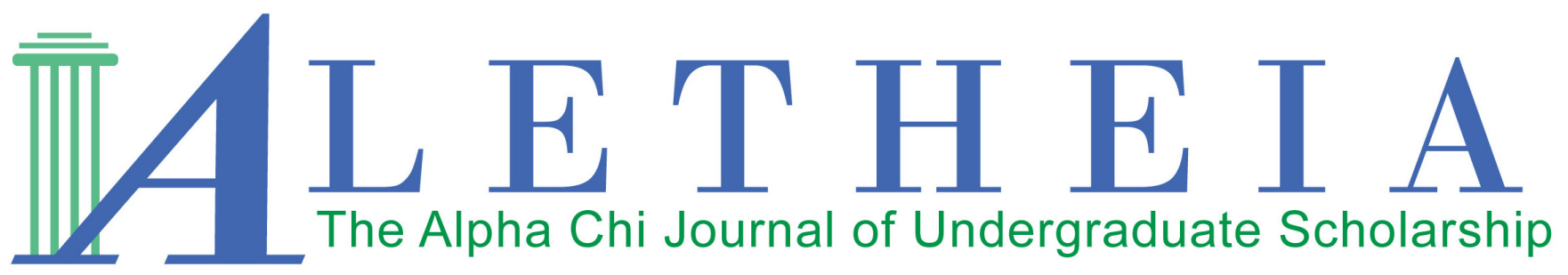

Volume 3 | Issue 2 | 2018

\title{
Religious Freedom and the Power of Interpretation: An Analysis of the History and Precedent Behind City of Boerne v. Flores, 521 U.S. 507 (1997)
}

\author{
Joe Barnello \\ University of Central Arkansas \\ Arkansas Gamma Chapter
}

Vol. 3(2), 2018

Title: Religious Freedom and the Power of Interpretation: An Analysis of the History and Precedent behind City of Boerne v. Flores, 521 U.S. 507 (1997)

DOI:

ISSN: $2381-800 \mathrm{X}$

Keywords: Supreme Court, Religious Freedom, City of Boerne, Constitutional Law This work is licensed under a Creative Commons Attribution 4.0 International License. Author contact information is available from tlindblom@alphachihonor.org or kvosevich@alphachihonor.org

\section{Aletheia-The Alpha Chi Journal of Undergraduate Scholarship}

- This publication is an online, peer-reviewed, interdisciplinary undergraduate journal, whose mission is to promote high quality research and scholarship among undergraduates by showcasing exemplary work.

- Submissions can be in any basic or applied field of study, including the physical and life sciences, the social sciences, the humanities, education, engineering, and the arts.

- Publication in Aletheia will recognize students who excel academically and foster mentor/mentee relationships between faculty and students.

- In keeping with the strong tradition of student involvement in all levels of Alpha Chi, the journal will also provide a forum for students to become actively involved in the writing, peer review, and publication process.

- More information can be found at www.alphachihonor.org/aletheia. Questions to the editors may be directed to tlindblom@alphachihonor.org or kvosevich@alphachihonor.org.

\footnotetext{
Alpha Chi is a national college honor society that admits students from all academic disciplines, with membership limited to the top 10 percent of an institution's juniors, seniors, and graduate students. Invitation to membership comes only through an institutional chapter. A college seeking a chapter must grant baccalaureate degrees and be regionally accredited. Some 300 chapters, located in almost every state, induct approximately 11,000 members annually. Alpha Chi members have been "making scholarship effective for good" since 1922.
} 


\title{
Religious Freedom and the Power of Interpretation: An Analysis of the History and Precedent Behind City of Boerne v. Flores, 521 U.S. 507 (1997)
}

\author{
Joe Barnello \\ University of Central Arkansas \\ Arkansas Gamma Chapter
}

\begin{abstract}
The Rehnquist Court was in a unique position when it decided the case of City of Boerne v. Flores, 521 U.S. 507 (1997). The case forced the Court to answer several questions ranging from the powers of Congress to the extent of religious liberty. In order to understand the reasoning behind Justice Anthony Kennedy's majority opinion, one must examine the legislative history of various legal fields. This paper examines the legal history of the Free Exercise Clause within the First Amendment, the powers of Congress, and the Separation of Powers Doctrine between co-equal branches of government. This analysis allows the reader to understand the four key axioms that survive today from the Court's decision within City of Boerne. First, Congress cannot enact legislation that changes the substantive nature of the Constitution. Second, it is permissible for laws of general applicability to inadvertently and indirectly interfere with religious practices. Third, the Constitution, not Congress, is the paramount law of the land. And fourth, the Court is bound to its own precedent, not to the will of Congress.
\end{abstract}

Keywords: Supreme Court, Religious Freedom, City of Boerne, Constitutional Law

In City of Boerne v. Flores, 521 U.S. 507 (1997), the Supreme Court added to the precedents of three major legal fields: Free Exercise Legislation, Congressional Powers (specifically the Enforcement Clause of the Fourteenth Amendment), and the Separation of Powers Doctrine. ${ }^{i}$ The Court had contemplated the answers to the latter two areas since the beginning of the nineteenth century in Marbury v. Madison, 5 U.S. (1 Cranch.) 137 (1803) and McCulloch v. Maryland, 17 U.S. (4 Wheat.) 316 (1819), but the Free Exercise Clause of the First Amendment had been a controversial court issue only since the 1960s. Through the voice of Justice Anthony Kennedy, the Boerne Court analyzed and condensed the legal histories of these domains to establish four important legal principles: first, Congress cannot enact legislation that changes the substantive nature of the Constitution; second, it is permissible for laws of general applicability to interfere with religious practices both inadvertently and indirectly; third, the Constitutionnot Congress - is the paramount law of the land; and fourth, the Court is bound to its own precedent rather than the will of Congress.

This article will begin by unpacking the legal history the Court employed when examining the facts of Boerne. In addition to the legal history, a brief explanation of the Religious Freedom Restoration Act and Congress's intended purpose are provided so that the reader may fully appreciate an analysis of the Boerne case. The 
objective of this article is to show the reader how Justice Kennedy and the Court reached the legal principles that will influence the judiciary for years to come.

The events of the Boerne case began when the St. Peter's Catholic Church in San Antonio, Texas, sought to expand their building in order to accommodate forty to sixty more parishioners during Sunday mass. However, before construction began, the Boerne City Council passed an ordinance that authorized the Historic Landmark Commission to approve or deny construction on historic buildings within historic districts, an ordinance which applied to the church. Archbishop Flores applied for a permit to expand St. Peter's Catholic Church, but the Commission denied the permit. Flores filed a claim within the United States District Court for the Western District of Texas, citing the Free Exercise Clause of the First Amendment and the Religious Freedom Restoration Act of 1993 (RFRA), which gave religious practices preference over state and local laws. The most important question the Court had to answer, then, was whether the enforcement clause within the Fourteenth Amendment granted Congress a wide-ranging power to interpret provisions of the Constitution and bind decisions of the judiciary.

\section{The Free Exercise Clause}

In order to answer this question, the Court had to interpret its past dockets in the fields mentioned above, beginning with Free Exercise Legislation. The Supreme Court first ruled on the Free Exercise Clause of the First Amendment in Reynolds v. United States, 98 U.S. 145 (1878). In that case, George Reynolds allegedly married a second wife and was arrested in violation of the federal anti-bigamy statute. However, Reynolds was also a member of the Church of Jesus Christ of Latter-Day Saints (the Mormon Church) and was a strict observer of the church's practices; thus, the doctrine in contention was the duty of male Mormons to practice polygamy. The Supreme Court had to decide "whether religious belief can be accepted as a justification of an overt act made criminal by the law of the land" (Reynolds v. United States, 162). According to Chief Justice Morrison Waite, religious beliefs were not the supreme law of the land; the Constitution was. Consequently, although "laws...cannot interfere with mere religious belief and opinions, they may with practices" (166). In other words, an individual could not use the practice of a religious belief (such as polygamy) as a viable defense against a generally applicable law that passed all other constitutional tests.

The Supreme Court established their modern stance on the Free Exercise Clause in Sherbert v. Verner, 374 U.S. 398 (1963), in which the petitioner sought unemployment compensation after being fired for refusing to work on Saturdays and the state of South Carolina refused to pay Sherbert unemployment since she declined other employment opportunities. These other opportunities would force Sherbert to work on Saturdays, which was contrary to her beliefs as a member of the Seventh-Day Adventist religion. Justice William J. Brennan's majority opinion held, “As so applied, the South Carolina statute abridged appellant's right to the free exercise of her religion, in violation of the First Amendment, made applicable to the states by the Fourteenth Amendment" (Sherbert v. Verner, 401). This decision created what would later be deemed the twopronged Sherbert Test. First, the court must determine if the party seeking redress has a sincere religious belief. If so, the government must show a compelling state interest for the law to stand. This notion of a compelling state interest is the crux of the strict scrutiny standard (the highest form of judicial review): in order for a law to pass strict scrutiny, the legislature must have a compelling state interest and the language must be narrowly tailored in pursuance of that interest.

The Court added to their religious freedom docket in Wisconsin v. Yoder, 406 U.S. 205 (1972), by adjudicating a case where a state failed to prove a compelling interest. Respondents were members of the Amish Mennonite Church convicted of violating a Wisconsin statute that required children to attend school until age 16 . The Yoders refused to send their children to public or private school after completing eighth grade; however, they did provide informal vocational education in the home after graduation. Additionally, the respondents sincerely believed that attending high school would endanger their children's religion. Chief Justice Warren Burger, writing for a unanimous court, applied the Sherbert test and held the Wisconsin statute unconstitutional on the grounds of free exercise of religion. First, the Court deemed the Amish religion legitimate through its long history, the respondents' religious belief sincere, and their beliefs endangered by the statute. Second, the court ruled that the two additional years of formal education did not constitute a compelling state interest to deny the Yoders their religious freedom. 
The Court once again upheld the Sherbert test in Thomas v. Review Board of the Indiana Employment Security Division, 450 U.S. 707 (1981). Thomas was a practicing Jehovah's Witness, a religion which forbids its followers from directly participating in war. The petitioner's company closed a foundry and transferred all employees to departments that dealt directly with the production of weapons; as a result, Thomas voluntarily terminated his employment to uphold his religious practice and sought relief when the state refused to provide unemployment. The Review Board argued that Thomas did not meet the requirement of terminating his employment "based upon good cause [arising] in connection with [his] work" (Thomas v. Review Bd. of Indiana Employment Sec. Div., 712). Chief Justice Burger upheld the Sherbert test over the single dissent of Justice William Rehnquist.

The Sherbert test remained the standard for the Supreme Court until Employment Division, Department of Human Services of Oregon v. Smith, 464 U.S. 301 (1990).i The two respondents were fired by a private drug rehabilitation organization for ingesting peyote, a hallucinogen. After their termination, the respondents applied for unemployment, but the state of Oregon denied them the benefit. The Oregon Department of Human Services argued that the two men violated the state statute that disqualified individuals from receiving unemployment benefits if they were fired for work-related misconduct. The respondents argued that the ingestion of peyote was part of a religious ritual. Despite this argument, the State Supreme Court ruled that the ingestion of peyote violated Oregon's controlled substance law. In his majority opinion, Justice Antonin Scalia (over the dissents of Justices Brennan, Thurgood Marshall, and Harry Blackmun) held that "The Free Exercise Clause permits the State to prohibit sacramental peyote use, and thus to deny unemployment benefits to persons discharged for such use" (Employment Div., Dep't of Human Res. of Oregon v. Smith, 872). Scalia defended this judgment by asserting the Court had never held that an individual's religious beliefs excused him from complying with a valid law of general applicability. In other words, Smith changed the test a law needed to pass in order to remain constitutional over a freedom of religion objection; Sherbert instated a strict scrutiny test, while Smith changed the precedent to a rational basis test, which shifted the burden of proof from the government to the aggrieved party. Under the rational basis test (the least stringent constitutional test against legislation), the petitioner must prove that a law created a substantial burden against their religious exercise, rather than the state having to prove a compelling need for the law. iii

After Smith, the Supreme Court was left with a crucial decision: it would have to determine which test to follow, Sherbert or Smith. By asserting that "the [Sherbert] test is inapplicable to an across-the-board criminal prohibition on a particular form of conduct," the Court seemed to stray from the strict scrutiny test and replace it with a rational basis test that favored the State (876). However, the Court could simply distinguish any religious freedom case in a similar manner and return to the Sherbert test, thereby freeing itself from limits in regard to disputes over the Free Exercise Clause at the time of City of Boerne v. Flores.

\section{Religious Freedom Restoration Act of 1993 (RFRA)}

In response to the Supreme Court's decision in Oregonv. Smith, Congress enacted the Religious Freedom Restoration Act of 1993 (RFRA) by a unanimous vote in the House and a 97-3 vote in the Senate. Congress invoked their power of enforcement stated within section five of the Fourteenth Amendment to protect the people against the State's denying due process or equal protection under the law. RFRA's purpose was two-fold. First, it intended "to restore the compelling interest test as set forth in Sherbert v. Verner, 374 U.S. 398 (1963) and Wisconsin v. Yoder, 406 U.S. 205 (1972) and to guarantee its application in all cases where free exercise of religion is substantially burdened" (42 U.S. Code Chapter 21B). Second, Congress wished to provide a defense against state and municipal governments substantially burdening the religious exercise of citizens (42 U.S. Code Chapter 21B). The code reads:

In general, government shall not substantially burden a person's exercise of religion even if the burden results from a rule of general applicability...[however,] government may substantially burden a person's exercise of religion only if it demonstrates that application of the burden to the person-is in furtherance of a compelling governmental interest; and is the least restrictive means of furthering that compelling governmental interest (42 U.S. Code Chapter 21B). 
Through this legislation, Congress clearly asserted that it disagreed with the Supreme Court's decision to overturn thirty years of precedent that established a strict scrutiny test toward the infringement of the free exercise of religion. RFRA was Congress's means of forcing the strict scrutiny test back upon the judiciary.

\section{Powers of Congress}

Another question that arose in Boerne was whether Congress possessed the power to enact RFRA. The first place to look for any discussion concerning the powers of Congress is Article I, section 8 of the Constitution, which clearly states, "The Congress shall have Power To..." followed by seventeen powers and the "necessary and proper" clause. In addition to these enumerated powers, the Supreme Court has provided four additional avenues for Congress to obtain power: implied powers, McCulloch v. Maryland (1819); inherent powers, Fong Yue Ting v. United States (1893); derived from amendments, South Carolina v. Katzenbach (1966); and resulting from treaties, Missouri v. Holland (1920). The Supreme Court first expanded the powers of Congress in McCulloch v. Maryland, where Chief Justice John Marshall said Congress possesses implied powers through the "necessary and proper" clause if the issue can be tied to an enumerated power and does not defy the Constitution. Although the Court enlarged the reach of Congress in Fong Yue Ting and Missouri v. Holland, these cases are not relevant to the issue at hand.

Ex Parte Virginia, 100 U.S. 339 (1879) was the first case to discuss the enforcement clauses of the Thirteenth and Fourteenth Amendments. The Court clearly interpreted the purpose of the Reconstruction Amendments as raising African Americans from conditions of inferiority and servitude which certain states sought to continue (Ex parte Commonwealth of Virginia, 344). In order to fulfill this purpose, Congress had the ability "to enforce by appropriate legislation." Subsequently, the Reconstruction Amendments sought to create "limitations of the power of the States and enlargements of the power of Congress" (345).

South Carolina v. Katzenbach established the aforementioned principle that Congress possesses the ability to gain power through the amendments to the Constitution. In this case, the controversy concerned a dispute over the constitutionality of the Voting Rights Act of 1965. The purpose of the congressional legislation was to identify and remedy the racial discrimination of specific states during federal elections. Chief Justice Warren (over the dissent of Justices Hugo Black) held that the enforcement clause of the Fifteenth Amendment ("The Congress shall have power to enforce this article by appropriate legislation") allowed Congress to pass any remedial legislation to prevent discrimination from the federal voting booth.

South Carolina v. Katzenbach concerns not only the powers of Congress but also the federal-state relationship. The Constitution's Tenth Amendment originally relinquished all powers not delegated to the federal government to the individual states. However, Chief Justice Warren declared, "The Fifteenth Amendment, which is self-executing, supersedes contrary exertions of state power, and its enforcement is not confined to judicial invalidation of racially discriminatory state statutes and procedures or to general legislative prohibitions against violations of the Amendment" (State of S.C. v. Katzenbach, 310). In other words, the Fifteenth Amendment gave Congress the supreme power over the states to enact binding legislation concerning equality and fairness in federal voting. ${ }^{\text {iv }}$

Justice Rehnquist furthered the notion of the national government's expanding power over the states through constitutional amendments in Fitzpatrick $v$. Bitzer, 427 U.S. 445 (1981). The case concerned male employees of Connecticut bringing suit against the state for sex-based discriminatory practices in the state's statutory retirement benefit plan. The question relevant to this discussion is whether the enforcement clause of the Fourteenth Amendment invalidated the principle of state sovereignty within the Eleventh Amendment. Rehnquist answered this question in the affirmative, writing:

When Congress acts pursuant to section five [of the Fourteenth Amendment], not only is it exercising legislative authority that is plenary within the terms of the constitutional grant, it is exercising that authority under one section of a constitutional Amendment whose other sections by their own terms embody limitations on state authority (Fitzpatrick $v$. Bitzer, 456).

Through this statement, Rehnquist established that the enforcement clause of the Fourteenth Amendment not only gave Congress power through Amendments (as 
in Katzenbach); it also gave Congress the ability to overstep the state sovereignty expressed in the Eleventh Amendment in cases that involved enforcement of the Equal Protection Doctrine.

The Court affirmed the Katzenbach precedent in Oregon v. Mitchell, 400 U.S. 112 (1970). The case once again concerned the Voting Rights Act; however, Mitchell dealt with issues broader than racial discrimination. The case observed amendments to the Voting Rights Act in three fields: changing the voting age for federal elections, abolishing literacy tests, and abolishing residency requirements for federal executive elections. Although the opinion of the Court was a plurality, all the Justices agreed "that Congress, in the exercise of its power to enforce the Fourteenth and Fifteenth Amendments, can prohibit the use of literacy tests or other devices used to discriminate against voters on account of their race in both state and federal elections" (Oregon v. Mitchell, 112). Justice Black's plurality decision tried to extend the power of the federal government in federal elections even more, but the important note is that Mitchell upheld the precedent that Congress could exercise legislative power stemming from the amendments of the Constitution.

It appeared that the Supreme Court possessed a limited docket concerning the powers of Congress derived from the enforcement clauses of the Reconstruction Amendments. The three cases mainly pertained to voting rights and racial discrimination, so it seemed clear that the Supreme Court was bound by precedent to allow Congress the power to pass legislation preventing racial injustice within the realm of federal elections. However, this precedent was extremely limited; the Court had the power to distinguish any case arising from the Enforcement Clauses outside of racial injustice and federal elections, which would allow the Court to determine a new legal principle (possibly to limit Congress's powers deriving from constitutional amendments).

\section{Separation of Powers (Between Co-Equal Branches)}

The last question that called for examination was whether the judiciary had the right to challenge the authority of Congress in enacting RFRA. Madison $v$. Marbury dominates this area of the law. In this landmark case, the Supreme Court defined the doctrine of separation of powers. Chief Justice Marshall declared that the Supreme Court possessed judicial review when he stated, "It is emphatically the province and duty of the judicial department to say what the law is. Those who apply the rule to particular cases, must of necessity expound and interpret that rule. If two laws conflict with each other, the courts must decide on the operation of each" (Marbury v. Madison, 177). Additionally, the Constitution is the paramount law of the land and is supreme to any ordinary act of the legislature. These two principles combined amount to the dominant standard that the courts have the sole power to interpret the Constitution and the laws of the United States, which gives the judicial branch the power to declare acts of Congress unconstitutional and, in effect, void.

The legal history behind the separation of powers between the judicial and legislative branches of the federal government is extensive, but not complicated. In short, the Court has never overturned the precedent established in Marbury v. Madison. The Court still maintains the power to interpret the Constitution and laws of the United States, and Congress maintains the power to enact legislation. However, problems arose when the Constitution gave the two branches concurrent power, such as the Enforcement Clause of the Fourteenth Amendment. "Two questions are raised by the vesting of concurrent power: Who has the final say, and what standard of review should the branch with final say apply to the other's actions?" (Cole, 35). In South Carolina v. Katzenbach and Oregon v. Mitchell, it appeared that the Court allowed Congress to possess the concurrent power to protect procedural due process; however, the Court had not answered the questions in regards to substantive rights - that is, not until City of Boerne v. Flores.

\section{Conclusion of Legal History}

Within City of Boerne v. Flores, the Supreme Court decided upon precedents within the areas of the Free Exercise Clause, Congressional Powers, and the Separation of Powers Doctrine. Seven years before City of Boerne, in Oregon v. Smith, the Court overturned the Sherbert test, which created a strict scrutiny rule for cases involving the Free Exercise Clause by lowering the standard of review to the rational basis test. This sudden change in precedent opened the Court to uncertainty in later decisions, an uncertainty which Congress tried to eliminate by enacting RFRA and ordering the Court back to the Sherbert test. Thus, in short, the Boerne Court 
needed to decide which authority to follow: the Court's standard established in Smith or the Congressionallyimposed standard that harkened back to Sherbert.

The Boerne Court also had a chance to decide the question of Congressional power delineating from the Enforcement Clauses of the Reconstruction Amendments. Until Boerne, the Court had primarily created and upheld Congressional powers in cases concerning race and voting rights. However, if a case fell outside the realm of racial discrimination within federal elections, the Court could easily circumvent precedent and create a new legal rule for the Enforcement Clauses in this uncharted field.

Although the Court possessed a wide domain in the areas of Free Exercise and Congressional Powers, the Separation of Powers Doctrine had remained largely untouched since Madison v. Marbury in 1803. Traditionally, the judiciary enjoys the power to interpret the law while the legislative branch holds the power to enact them. However, the Separation of Powers Doctrine granted concurrent power to both the legislature and the judiciary and thus created a legal "gray area." The Court had answered this question under the umbrella of procedural due process (the principle that certain steps are followed before the government can infringe upon a citizen's life, liberty, or property) in South Carolina v. Katzenbach, where it gave Congress the power to legislate in the defense of procedural due process. However, the Court remained silent on this issue regarding substantive due process (the idea that the Fourteenth Amendment protects certain rights, such as privacy). Therefore, the Boerne Court wielded the power to create a major innovation in this area of the law.

\section{Analysis of the Case}

Upon consideration of the facts presented at the beginning of this article, The United States District Court for the Western District of Texas originally ruled in favor of the defendant, the City of Boerne. The district court ruled that Congress exceeded the scope of the Enforcement Clause within section five of the Fourteenth Amendment and upheld the municipal ordinances of Boerne. Archbishop Flores filed an appeal, and the Fifth Circuit Court of Appeals reversed the decision of the lower court. The appellate court found Congress's enactment of RFRA to be constitutional under the scope of the enforcement clause within the Fourteenth Amendment. The City of Boerne then sought a writ of certiorari, which the Supreme Court granted (City of Boerne v. Flores, 507).

City of Boerne saw a divided and audible Court on the issue of whether or not Congress exceeded its power by enacting RFRA. Justice Kennedy (with whom Chief Justice Rehnquist and Justices John Paul Stevens, Scalia, Clarence Thomas, and Ruth Bader Ginsburg joined) wrote the majority opinion for the Court. After presenting the facts of the case and a brief legislative history behind the enactment of RFRA, Kennedy began to adjudicate on the issues of the current case.

Kennedy began his reasoning by first specifying that the national government is an entity built upon enumerated powers ratified by the Constitution and affirmed by the Supreme Court in McCulloch $v$. Maryland. He also made clear that the Court possesses the power to rule on the constitutionality of federal laws that are defined and limited. Therefore, he concluded, the question at hand is whether or not RFRA falls within the constitutional limits of the federal government. Flores and the government argued that the Enforcement Clause of the Fourteenth Amendment allowed Congress to pass RFRA as a proper implementation of the Due Process Clause (of the same amendment) and the Free Exercise Clause (of the First). Kennedy acknowledged that the Enforcement Clause is "a positive grant of legislative power to Congress," as seen in Katzenbach v. Morgan and Ex Parte Virginia, which allows Congress to protect these liberties; however, Kennedy further stated that the power is not without limits, as seen in Oregon v. Mitchell (517-518).

To Justice Kennedy, the limit was that the Enforcement Clause grants power to enact remedial rather than substantive legislation. ${ }^{\mathrm{vi}}$ In other words, Congress only holds the power to enforce the protection of individual liberties; they do not have the power to change the meaning-or scope-of an individual right. Kennedy admitted that a fine line exists between remedial and substantive legislation. He then drew the line by stating, "There must be a congruence and proportionality between the injury to be prevented or remedied and the means adopted to that end. Lacking such a connection, legislation may become substantive in operation and effect" (520). Put simply, Congress can enact legislation that rights an established wrong against a defined liberty accepted by society (remedial); 
however, Congress cannot create or limit the rights of the people through legislation (substantive).

To prove this point, Kennedy began by examining the congressional record and the legislative record. In the latter, Kennedy examined the proceedings of the $39^{\text {th }}$ Congress, which drafted the Fourteenth Amendment. Originally, the Joint Committee responsible for drafting the amendment proposed section five as giving Congress "power to make all laws necessary and proper to secure to the citizens of each State all privileges and immunities of citizens in the several States" (520). It appears that Kennedy agreed with the Congressmen who staunchly objected to this draft on the grounds that it would have ceded Congress power to enact substantive laws, which went against the intent of the Framers of the Constitution. Kennedy mentioned this rejection as proof that no suggestion of Congress having substantive, non-remedial power under the Fourteenth Amendment exists within the Court's case law (527). If Congress had this substantive power, then the Constitution would no longer be the law of the land; Congress would.

Kennedy then turned to the second half of his opinion to determine whether RFRA was a proper exercise of remedial power or an unconstitutional enactment of substantive enforcement legislation. Flores and the government argued that if Congress could enact legislation to invalidate state and local laws with discriminatory effects by invoking the Equal Protection Clause, then Congress should be able to do the same to promote religious liberty (529). Kennedy in his majority opinion did not agree with this contention for one main reason: "the appropriateness of remedial measures must be considered in light of the evil presented" (530). Kennedy went on to analyze the evils prevented through the enactment of the Voting Rights Act compared to RFRA. He observed that the two areas were quite different. While the Voting Rights Act sought to prohibit a laundry list of laws on record that directly resulted in racial discrimination against African Americans, RFRA only attacked laws of general applicability that subsequently affected religion. In other words, while a record of racial discrimination existed and needed to be extinguished in regard to the Voting Rights Act, the equivalent did not exist in the realm of religious discrimination.

Kennedy further distinguished RFRA from the Voting Rights Act for three reasons. First, RFRA applied to every agency and official in all tiers of government.
Second, RFRA applied to all federal and state laws adopted before and after 1993. Third, RFRA had no termination date or mechanism (532). For these reasons, Kennedy found, "The stringent test RFRA demands of state laws reflects a lack of proportionality or congruence between the means adopted and the legitimate end to be achieved" (533). In fact, RFRA's scope went even further than the Smith Court's judgment of the Free Exercise Clause, but Kennedy did not want to elaborate on the topic and stray from his own reasoning.

Kennedy's majority opinion struck down RFRA as unconstitutional legislation. The majority reasoned that the Enforcement Clause of the Fourteenth amendment did not give Congress substantive power to alter individual liberties found within the Constitution, which was precisely what the Court saw Congress doing through RFRA. Kennedy, through the majority opinion, concluded that the Constitution-not Congress - is the supreme law of the land; therefore, Congress does not possess the power to enact legislation that would substantially change the Constitution.

In addition to Justice Kennedy's opinion for the Court, Justices Stevens and Scalia wrote separate concurrences while Justices Sandra Day O'Connor, David Souter, and Stephen Breyer wrote dissents. Justice Steven's concurrence was short and simply argued: RFRA is a law respecting the establishment of religion; therefore, the law is unconstitutional. Stevens reasoned that if the building in this case were a museum owned by an atheist, the owner could not invoke RFRA as a defense. Consequently, RFRA created a clear preference for religion, a preference which was prohibited by the Establishment Clause of the First Amendment.

Justice O'Connor began her dissent by clearly agreeing with the opinion of the majority regarding RFRA: it is an unconstitutional reach of Congress's power under the Enforcement Clause of the Fourteenth Amendment. However, O'Connor dissented on the grounds that she would use this case to re-examine the precedent in Oregon v. Smith. In fact, O'Connor "would direct the parties to brief the question whether Smith represents the correct understanding of the Free Exercise Clause and set the case for reargument" (544-545). She clearly believed that Smith adopted an improper standard for deciding cases surrounding the Free Exercise Clause that harmed religious liberty. If the case were reargued, O'Connor would "return to a rule that requires government to justify any substantial 
burden on religiously motivated conduct by a compelling state interest and to impose that burden only by means narrowly tailored to achieve that interest" (548). In other words, O'Connor would return to the standard of strict scrutiny outlined by the Sherbert Court and its thirty years of established precedent.

The remainder of her dissent is an extensive list of evidence drawing from debates and laws in the colonies, state constitutions under the Articles of Confederation, and writings and debates from Founding Fathers during the ratification period. O'Connor's takeaway from all these sources is that "The Religion Clauses of the Constitution represent a profound commitment to religious liberty" (564). Therefore, the Smith Court strayed from the purpose of the Constitution, and it is the duty of the Court to return to that purpose through a re-argument of the current case.

While the short dissents of Justices Souter and Breyer mostly agree with the dissent of O'Connor, Souter wanted to wait for the case to be re-argued before he completely joined O'Connor's reasoning. Additionally, Breyer agreed with O'Connor's dissent, but did not find it necessary to expound upon the scope of the Enforcement Clause of the Fourteenth Amendment.

Justice Scalia's concurrence took the opposite perspective in relation to O'Connor's dissent. In fact, Scalia directly criticized O'Connor and attacked every piece of her explanation for "either [having] little to say about the issue or is in fact more consistent with Smith than with [O'Connor's] dissent's interpretation of the Free Exercise Clause" (538). Furthermore, Scalia believed that if O'Connor's reasoning behind the purpose of the Free Exercise Clause were true, then early examples of generally applicable laws being struck down for religious purposes would exist; however, O'Connor failed to mention any such instance. Therefore, O'Connor's dissent did nothing to undermine the ruling of the Smith Court, according to Justice Scalia.

\section{Assessment and Conclusion of the Case}

Justice Kennedy established two rulings within his majority opinion. First, RFRA is unconstitutional because it is constitutionally inconsistent for Congress to alter the meaning of the Free Exercise Clause. Second, the Court will decide cases and controversies based on its own precedents, not the legislation of Congress (such as RFRA), in accordance with the doctrines of separation of powers and the federal balance. While one fair critique proposed by Judge McConnell and subsequent scholars is that Justice Kennedy's approach within Boerne is overly favorable of the judiciary's powers in relation to Congress, I believe that Justice Kennedy made a respectable decision according to precedent and that his reasoning created a fluid argument that coincided with his two conclusions (Calabresi and Stabile, 1433). Although the bulk of the facts in this case lend Boerne to appear as a Free Exercise case, Kennedy did a brilliant job of placing the case in the context of the powers of Congress, separation of powers, and the federal balance - unlike the three dissents, which tried to make this strictly a religious freedom case.

The legislative history behind the powers of Congress clearly established that Congress could derive powers from amendments (South Carolina v. Katzenbach) and that Congress could overstep state sovereignty when acting pursuant to the Equal Protection Clause (Fitzpatrick v. Bitzer); however, each of the cases pertaining to the Enforcement Clause of the Fourteenth Amendment dealt with laws that clearly created situations of racial or sex-based discrimination. Therefore, I believe that the Court possessed the ability to distinguish cases concerning enforcement legislation prohibiting the incidental burden upon religious practices by generally applicable laws, which is the exact path Justice Kennedy followed in his reasoning.

The legislative history pertaining to the doctrine of separation of powers is one of the clearest areas of constitutional law. Marbury v. Madison established that the Supreme Court possesses judicial review, which grants the justices the ultimate authority to rule upon the constitutionality of federal legislation. Additionally, the Constitution is the paramount law of the land. Therefore, the Court should be bound by its own precedent, not the desired precedent of Congress. If Congress could pass a law binding the Courts to a specific decision (in regards to individual liberties), then the whole doctrine of separation would disappear, and Congress would reign supreme over the judicial branch. Additionally, if Congress could change the substance of provisions within the Constitution through legislative action, then Congress's power would become superior to the Constitution. In other words, the legislative branch cannot stretch their power beyond the scope of the Constitution.

Michael W. McConnell leads the secondary literature of City of Boerne v. Flores in his analysis "Institutions and Interpretation: A Critique of City 
of Boerne v. Flores." Within the article, McConnell explicitly states, "the Religious Freedom Restoration Act was a legitimate exercise of Congress's power to enforce the provisions of the Fourteenth Amendment' (McConnell, 156). McConnell seems surprised that Justice Kennedy weighed heavily in favor of judicial supremacy over Congress. His conclusion is that the Court erred in striking down the constitutionality of RFRA. Furthermore, he writes that the Court was unjustified in not considering the opinion of Congress in respects to the Free Exercise question presented in Boerne. This critique seems more than fair; however, it is important to reiterate that in his opinion, Justice Kennedy side-stepped the Free Exercise policy questions and focused on the proper powers of Congress as defined by the Constitution. Therefore, despite the proper policy critiques laid out by Mitchell, Justice Kennedy's opinion still seems justifiable in regards to the precedents established in the fields of the Separation of Powers Doctrine and the Powers of Congress.

Other scholars such as Christopher L. Eisgruber and Lawrence G. Sager have commented on the opinions within Boerne, detailing the complex precedents established within City of Boerne v. Flores in their 1997 article "Congressional Power and Religious Liberty After City of Boerne v. Flores" (Eisgruber and Sager, 139). Within the article, they make several predictions for future Court decisions. First, they see this case as the death sentence for Sherbert's compelling interest test. They claim that the Free Exercise and the Establishment Clause, as seen in Justice Stevens concurrence, are quickly merging, which makes the Sherbert test "normatively indefensible and practically unworkable" (139). In other words, a test that protects the free exercise of religion at the expense of the establishment of religion inherently contradicts the converging rights. The second stance of Eisgruber and Sager deals with the separation of powers. They chastise Congress for going beyond its typical means of legislation. Congress tried to deem the compelling interest test workable, even as the Court rejected it as unworkable. The authors call RFRA an "enactment of a shadow constitution, with the judiciary obliged to play an unwilling supportive role" (136). Their discussion seems to lead to the conclusion that Congress will not be permitted to play a supervisory role over the Court for some time.

Suzanna Sherry details another stance on the Court's opinions in her article "The Unmaking of a Precedent," which examines the effects of City of Boerne on subsequent decisions up to the 2003 term. She states that the primary question concerning the power of Congress derived from amendments became whether "Congress was enforcing existing constitutional rights or was instead creating new rights" (Sherry, 236). Those enforcing would be constitutional while those creating new rights were struck down. Sherry contends that the Court did not uphold a single federal statute under the above test. In fact, the Court struck down five federal acts in the six terms following the City of Boerne decision (the Age Discrimination in Employment Act in Kimel v. Florida Board of Regents, 528 US 62 (2000); the Americans with Disabilities Act in Board of Trustees of the University of Alabama v. Garrett, 531 US 356 (2001); The Fair Labor Standards Act in Alden v. Maine, 527 US 706 (1999); the Lanham Act in College Savings Bankv. Fla Prepaid Postsecondary Educ Expense Bd, 527 US 666 (1999); and the Patent and Plant Variety Protection Remedy Clarification Act in Fla Prepaid Postsecondary Educ Expense Bd v. College Savings Bank, 527 US 627 (1999) (236). The remainder of her article details how the Court distinguished Nevada Department of Human Resources v. Hibbs, 123 S Ct 1972 (2003), from the precedent established in the previous cases.

Ultimately, City of Boerne v. Flores contains several key axioms that survive today. First, Congress cannot enact legislation that changes the substantive nature of the Constitution. Second, it is permissible for laws of general applicability to inadvertently and indirectly interfere with religious practices. Third, the Constitution, not Congress, is the paramount law of the land. And finally, the Court is bound to its own precedent, not to the will of Congress. While few people dispute the fact that the Constitution is the supreme law of the land and that Congress is subject to follow its provisions, the other three principles are topics of debate. Scholars discuss whether the Enforcement Clauses of the Reconstruction Amendments give Congress substantive power in addition to remedial power, and the Supreme Court itself disagrees with the position that laws of general applicability can permissibly interfere with religious practices for the thirty years following Sherbert. Furthermore, many people would also argue that Congress enacts legislation that the judiciary is bound to interpret; therefore, Congress arguably possesses the power to change the precedents of the judiciary through legislative means. While scholars can argue these three legal principles, one fact remains: the Court's ruling in City of Boerne v. Flores is an essential piece to each of these discussions. 
Works Cited

"42 U.S. Code Chapter 21B - RELIGIOUS FREEDOM RESTORATION." Cornell University. Accessed Oct. 1, 2017. https://www.law.cornell.edu/uscode/text/42/ chapter-21B.

Calabresi, Steven G. and Nicholas P. Stabile. "On Section 5 of the Fourteenth Amendment." 11 U. Pa. Const. L. 1431, (2009).

City of Boerne v. Flores, 521 U.S. 507, (1997).

Cole, David. "The Value of Seeing Things Differently: Boerne v. Flores and Congressional Enforcement of the Bill of Rights," 1997 Sup. Ct. Rev. 31, 35 (1997).

Eisgruber, Christopher L. \& Lawrence G. Sager. "Congressional Power and Religious Liberty

After City of Boerne v. Flores," 1997 Sup. Ct. Rev. 79, (1997).

Employment Div., Dep't of Human Res. of Oregon v. Smith, 494 U.S. 872, (1990).

Ex parte Commonwealth of Virginia, 100 U.S. 339, (1879).

Fitzpatrick v. Bitzer, 427 U.S. 445 (1981).

Marbury v. Madison, 5 U.S. 137 (1803).

McConnell, Michael W. "Institutions and Interpretation: A Critique of City of Boerne v. Flores." 111 Harv. L. Rev. 153. (1997).

Oregon v. Mitchell, 400 U.S. 112 (1970).

Reynolds v. United States, 98 U.S. 145, (1878).

Sherbert v. Verner, 374 U.S. 398, (1963).

South Carolina v. Katzenbach, 383 U.S. 301, (1966).

Sherry, Suzanna. "The Unmaking of a Precedent," 55 Sup. Ct. Rev. 231, 236 (2003).

Thomas v. Review Bd. of Indiana Employment Sec. Div., 450 U.S. 707, (1981).
Endnotes

i As Michael McConnell expresses in his legal comment "Institutions and Interpretation: A Critique of City of Boerne v. Flores" (McConnell, 154).

ii The last case to uphold the Sherbert test was Hobbie v. Unemployment Appeals Comm'n of Florida, 480 U.S. 136 (1987) with Justice Brennan speaking for the Court over the dissent of Chief Justice Rehnquist. The facts and decision practically mirror Sherbert.

iii As McConnell expressed in his note, the general scholarly consensus towards Smith is critical of its opinion to overturn the established precedent (McConnell, 154).

iv This theory of federal supremacy over the states regarding the Voting Rights Act can also been seen in Katzenbach v. Morgan, 384 U.S. 641 (1966), from the same term of South Carolina v. Katzenbach.

v The Eleventh Amendment reads, "The Judicial power of the United States shall not be construed to extend to any suit in law or equity, commenced or prosecuted against one of the United States by Citizens of another State, or by Citizens or Subjects of any Foreign State."

vi Kennedy draws upon South Carolina v. Katzenbach to make this distinction. 
